\title{
Ecology of the Long-Tailed Jaeger at Lake Hazen, Ellesmere Island
}

\author{
WILLIAM J. MAHER ${ }^{1}$
}

\begin{abstract}
Breeding density, timing, chick growth and food habits of a high population of long-tailed jaeger were studied in 1966 . Breeding density fluctuated from 0 to 2 pairs per square mile (259 hectares) from 1961 to 1966; peak years were 1962 and 1966. Breeding success was 12 to 13 per cent of eggs laid in 1966, and only 1 of 7 nests in 4 low years was successful. Published evidence suggests breeding success in peak years is usually high. Egg-laying dates vary widely between years and within populations. Occurrence of food items in 242 fresh and 710 old regurgitated pellets was, respectively, 90.1 and 94.0 per cent lemming remains. Occurrence of other vertebrate prey (mostly birds) was 18.6 and 8.0 per cent. Snow buntings were the most frequent bird (79.5 and 72.5 per cent), and shorebirds the next most frequent group ( 9.1 and 21.6 per cent). The percentage of juveniles among passerine birds was 83 and 79.4 and among shorebirds was 75 and 91 . Insects occurred in 30 per cent of new pellets.
\end{abstract}

RÉSUMÉ. Écologie du Labbe à longue queue du lac Hazen, île d'Ellesmere. On a étudié en 1966 la densité de reproduction, la distribution chronologique, la croissance des poussins et les habitudes de nutrition d'une importante population de labbes à longue queue. De 1961 à 1966, la densité de reproduction a fluctué de 0 à 2 couples par mille carré ( 259 hectares), avec des sommets en 1962 et 1966 . De 12 à 13 pour cent des oufs pondus en 1966 ont atteint l'éclosion, mais dans les 4 années creuses, seul un nid sur 7 était productif. Tous les indices suggèrent que dans les bonnes années, la "réussite" reproductive était très grande. Les dates de ponte varient beaucoup d'une année à l'autre et selon les groupes. La proportion des aliments dans les boulettes régurgitées - 242 fraîches et 710 anciennes - était respectivement de 90.1 et 94.0 pour cent de restes de lemmings. Pour les autres proies vertébrées (surtout des oiseaux), elle était de 18.6 et de 8.0 pour cent. Le plectrophane des neiges était l'oiseau le plus fréquent (79.5 et 72.5 pour cent), suivi des oiseaux de mer (9.1 et 21.6 pour cent). Chez les passereaux, le pourcentage d'oiseaux juvéniles était de 83 et 79.4, et chez les oiseaux de mer, il était de 75 et 91 . Les insectes étaient présents dans 30 pour cent des boulettes fraîches.

РЕЗЮМЕ. Экология поморника длиннохвостого на овере Хейзен (о. Эльмира). В 1966 году были проведены исследования встречаемости гнезд, времени кладки яиц, роста птенцов и употребляемой пици для большой популяции поморника длиннохвостого. Встречаемость гнездящихся птиц в период с 1961 по 1966 гг. изменялась от 0 до 2 пар на квадратную милю (259 гектар), причем напболышее число гнездящихся птиц наблюдалось в 1962 и 1966 годах. В 1966 году птенцы вылупились из 12-13\% всех отложенных яиц, в то время как в течение четырех неблагоприятных лет, лишь в одном гнезде из семи появились птенцы. Опубликованные данные показынают, что рождаемость птиц в благоприятные годы обыкновенно высока. Время кладки яиц сильно изменяется от года $k$ году и от популяции $k$ популяции. Пищевые компоненты, найденные в 242 пробах свежей и 710 пробах старой отрыжки, состояли, соответственно, из 90,1 и 94,0\% остатков лемминга. Содержание в пище других позвоночных (преимущественно птиц) составляло 18,6 и 8,0\%. Из птиц наиболее часто в пищу употреблялась пуночка $(79,5$ и 72,5\%), затем следовали прибрежғные птицы $(9,1$ и $21,6 \%)$. Процент молодняка среди употребляемых в пищу птиц из семейства воробьиных составлял 83 и $79,4 \%$, а ив прибрежных птиц - 75 и $91 \%$. В $30 \%$ всех новых проб были найдены насекомые.

${ }^{1}$ Department of Biology, University of Saskatchewan — Canada. 


\section{INTRODUCTION}

The long-tailed jaeger (Stercorarius longicaudus) has a holarctic breeding range which in North America extends across the arctic from northern Ellesmere Island south to central Alaska, northern Mackenzie, southern Keewatin, Southampton Island and northern Quebec. At its maximum width its breeding range spans more than 20 degrees of latitude from about $60^{\circ} \mathrm{N}$. on Hudson Bay to the northermost land at $83^{\circ} \mathrm{N}$.

On the North American mainland and in parts of the Canadian Arctic Archipelago its range overlaps with the pomarine jaeger (Stercorarius pomarinus) and the parasitic jaeger (Stercorarius parasiticus). Studies in northern Alaska indicate (Maher 1961) that both of these species are potential competitors of the longtailed jaeger. The ecology of this species in the High Arctic is of interest because on Ellesmere Island it appears to be free from interactions with other jaeger species, and because in the High Arctic it is at the northern periphery of its extensive range.

This paper reports the ecology of the long-tailed jaeger studied in 1966 at Hazen Camp, Ellesmere Island $\left(81^{\circ} 49^{\prime} \mathrm{N} ., 7^{\circ} 18^{\prime} \mathrm{W}\right.$.).

\section{METHODS}

The methods usual in field ornithology were employed and need little comment. Nests of breeding jaegers are readily found as the birds are usually bold and aggressive in defending the nest area. Nest localities can be marked on aerial photographs and inter-nest distances measured. Distances determined in this way are probably accurate to 100 feet. For study of chick growth, nests were enclosed with a wire fence 1 foot high and approximately 10 feet in diameter, and chicks were weighed in the field to $1 \mathrm{dg}$. with a triple beam balance. Food habits were studied from observation and from regurgitated pellets of food remains collected on jaeger roosting sites (prominent mounds or boulders), the vicinity of nests and in nest enclosures. They were individually wrapped in the field. A shiny dried mucus coat allowed separation of the 1966 pellets from older ones. Acknowledgement is given at the end of this paper to those whose observations for years other than 1966 are included herein.

\section{ENVIRONMENT}

Hazen Camp is on the northwest shore of Lake Hazen, a large deep oligotrophic lake, 47 miles long and approximately 7 miles wide. The United States Range, 9,000 feet in elevation, bounds the area on the north. Foothills of this range (the Garfield Range) are within 25 miles of the camp. Savile (1964), and Oliver and Corbet (1966) have described the vegetation, habitats and general ecology of an 8.6-square-mile study area around Hazen Camp. A brief description will suffice here.

The Hazen Camp study area is on a south-facing slope of the Garfield Range ascending in slightly over 2 miles, from an elevation of 518 feet at Lake Hazen to 3,280 feet at the top of Mount McGill. It has 3 topographic areas: boulder 
and talus slopes of Mount McGill, foothills, and the lowlands. This study was made almost entirely on the foothills and lowlands of the study area.

The climate is characterized by long cold dry winters and short cool summers. The daily mean temperature is above $32^{\circ} \mathrm{F}$. from the first half of June to late August. Seasonal maximum daily temperatures are usually in early August. The mean temperature in July is $42.7^{\circ} \mathrm{F}$. and the frost free season (days with minimum temperature above $32^{\circ} \mathrm{F}$.) averages 55 days: 22 June to 15 August. Temperatures differ greatly between years; thus the mean temperature for the active season (16 June to 15 August) from 1962 to 1966 was, respectively, $45.5^{\circ} \mathrm{F}$, $41.4^{\circ} \mathrm{F}$, $38.8^{\circ} \mathrm{F}$., $40.9^{\circ} \mathrm{F}$. and $42.3^{\circ} \mathrm{F}$, with a 5 -year average of $41.8^{\circ} \mathrm{F}$. The frost-free season in these years ranged from 41 days (1964) to 75 days (1962). Temperature data are from Corbet (1967).

Annual precipitation at Eureka, Ellesmere Island, averages about 1.74 inches, 70 per cent of which falls in summer.

Southern exposure and the protective mountains to the north cause a relatively benign summer climate which has been commented on by several authors (Parmelee and MacDonald 1960; Savile 1964). As a consequence of the extreme aridity, vegetation is low and sparse. Rich vegetation develops only where moisture persists through the summer; i.e., pond margins, marshes, springy slopes and permanent and semipermanent streams. Mesic areas are covered with extensive stands of Dryas integrifolia, either in almost pure stands or mixed with Kobresia or Salix sp. Sand, gravel and clay soils support sparse vegetation.

\section{POPULATION NUMBERS}

There are no satisfactory data on economic breeding density of long-tailed jaegers from the High Arctic of Canada or Greenland.

Twelve pairs of jaegers bred on the Hazen Study Area in 1966, including 1 pair which bred on Johns Island (Fig. 1); 10 nests were located. One pair (14) which apparently bred in the delta of Blister Creek was not located until 2 August when it had 1 chick just able to fly. Another pair (11), which did not breed, occupied a territory from 24 June until 5 July. A second non-breeding pair (15) was present near the northern part of the area on 6 and 13 June. The breeding density, excluding the pair on Johns Island, was 11 pairs on approximately 5.5 square miles, or 2 pairs per square mile.

Six measurements on aerial photographs of distance to nearest neighbour among the 10 nests ranged from 1,050 to 4,190 feet, with a mean of 2,760 . When measurements among all nests were used, there were 12 distances ranging from 1,050 to 5,000 feet with a mean of 3,370 . In these measurements the first nest of pair 1 (1A) was used; pair 11 (which did not breed) and pair 14 (whose nest was not located) were excluded.

Use of inter-nest distances as a measure of dispersion assumes that the nest is in or near the territory centre. Several observations suggest that this is not necessarily true of the long-tailed jaeger. Pair 1 had two successive nests 1,300 feet apart in 1966. The activity of pair 3 was centred about 2,000 feet northeast of the nest site before the eggs were laid. Both members of pair 7 incubated a nest 


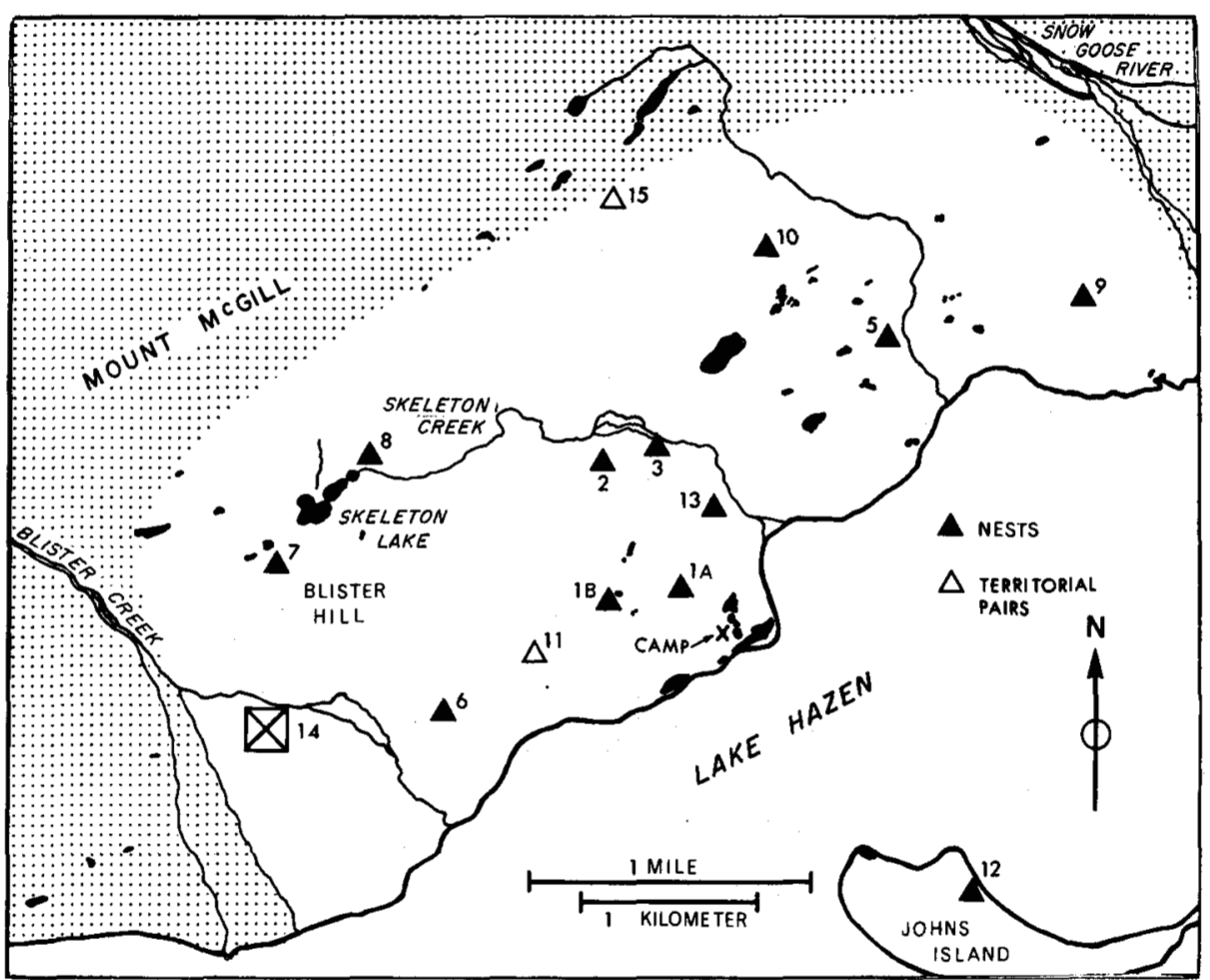

FIG. 1. Hazen Camp Study Area with distribution of 1966 jaeger population and portion of study area surveyed in detail.

scrape on 17 June; a nest relief was seen. The first egg of this pair was laid more than a week later, on 25 June, approximately 500 feet from the first nest scrape. Location of the nest on a territory seems to depend in part on the local attachment of the pair at the time the eggs are laid. Since nests are not necessarily in the centre of a territory, the distances among all nests is probably a better measure of the dispersion of these pairs than the distances to nearest neighbours.

The number of pairs breeding at Lake Hazen has varied considerably between years. Tener (in Savile and Oliver 1964) noted "some" nesting in 1958, apparently none bred in the study area in 1961 and six pairs bred in 1962. Two pairs bred in 1963 and 1964, and one in 1965. In 1965 several territorial pairs were noted in June which apparently did not breed. Three pairs bred in 1967 and 2 in 1968.

Breeding density in 1963 and 1964 was 2 pairs on approximately 4.75 square miles, or 0.42 pairs per square mile. In 1965 one pair bred on 5.6 square miles, a density of 0.18 . The 1966 density was 2 pairs per square mile, and 2 pairs in 1968 bred on approximately 2.5 square miles, a density of 1.2 . Thus, the breeding population of jaegers at Hazen Camp has varied from 0 to 11 pairs and the density from 0 to 2 pairs per square mile of occupied habitat.

Fig. 2 shows the approximate locations of nests in 1963 to 1965,1967 and 1968. Comparison with the locations of some 1966 nests suggests that at least 


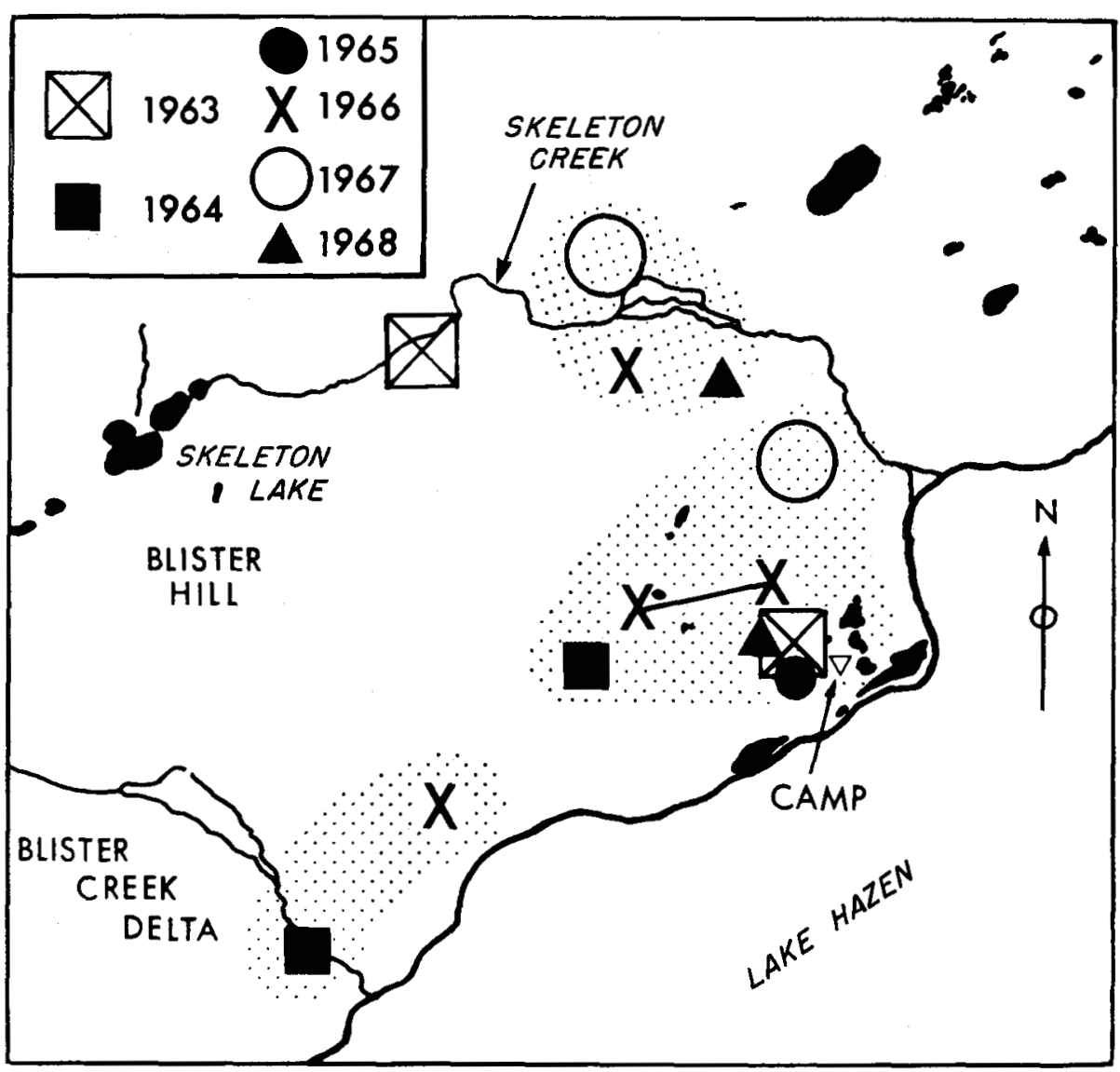

FIG. 2. Locations of jaeger nests in 1963, 1964, 1965, 1967 and 1968. Locations of 1966 nests are added when they are thought to be the same pairs as were present in other years.

three pairs (Nos. 1, 2 and 6) have bred more than once on the same territory. Thus the Lake Hazen long-tailed jaeger population probably consists of at least some pairs that have permanent territories to which they return each year and on which they breed in years when conditions are acceptable. The population was probably augmented in 1966, by transient birds which were attracted by the food supply.

The occurrence of permanent territories is supported by some banding data. Both adults of pair 1 were banded in 1963. The pair returned and bred in 1964. In 1965 a new male mated with the original female. The original male was apparently displaced in that year as very prolonged territorial disputes were noted near camp. In 1966 the female was rebanded and the male banded. The pair definitely bred in 1967 and 1968. In 1966 the original male of pair 1, banded in 1963 , was accidentally caught on a fish line and killed.

A member of another breeding pair, probably the female, banded in 1964, was a member of pair 6 in 1966 (Fig. 2).

Thus the female of pair 1 bred on the territory for at least 6 seasons and the 
male for 4. The nest of pair 1 in 1963 was in the same spot as the nest in 1962 suggesting that the female was there the year before being banded making a total of seven seasons.

\section{BREEDING SUCCESS}

There are few data on breeding success of the long-tailed jaeger in the High Arctic, although the observations of Manniche (1910) suggest high success. Upon his arrival in high-arctic Greenland in mid August 1906, fledglings were still being fed on territory. He observed: "all pairs with but one exception, had only one young, though the rule as far as I know should be two." Apparently 1908 was similar to 1906 and in addition he noted that the majority of nests had two eggs. It appears that success in both years was high, although less than 50 per cent of the number of eggs laid. Similarly we can infer from Savile and Oliver (1964) that the 1962 jaeger population at Lake Hazen had high success, but also less than 50 per cent.

TABLE 1. Hatching and fledging success of long-tailed jaegers at Hazen Camp.

\begin{tabular}{ccccccccc}
\hline Year & $\begin{array}{c}\text { Nests } \\
\text { found }\end{array}$ & $\begin{array}{c}\text { Chicks } \\
\text { found }\end{array}$ & $\begin{array}{c}\text { No. } \\
\text { clutches }\end{array}$ & $\begin{array}{c}\text { Clutch } \\
\text { size }\end{array}$ & $\begin{array}{c}\text { No. } \\
\text { eggs }\end{array}$ & $\begin{array}{c}\text { No. } \\
\text { hatch }\end{array}$ & $\begin{array}{c}\text { No. } \\
\text { fledge }\end{array}$ & $\begin{array}{c}\text { Per cent } \\
\text { success }\end{array}$ \\
\hline 1963 & 2 & & 2 & 2.0 & 4 & 2 & 0 & 0 \\
1964 & 2 & & 2 & 1.0 & 2 & 0 & & 0 \\
1965 & 1 & & 1 & 1.0 & 1 & 1 & $0(?)$ & 0 \\
1966 & $8 \mathrm{a}$ & 1 & 8 & 2.0 & 16 & 6 & 2 & $12-13$ \\
1967 & 3 & & $2 \mathrm{~b}$ & 1.5 & 3 & 1 & $?$ & $?$ \\
1968 & 2 & & 2 & 1.0 & 2 & $1 \mathrm{c}$ & 1 & 100 \\
\hline
\end{tabular}

aIncludes re-nest by pair 1 ; nests penned for growth study are not included.

bClutch of one nest not known.

cEgg was removed from one nest by G. Bromley.

Breeding success at Lake Hazen from 1963 to 1968 (Table 1), has usually been low. In 1966, when a high population of jaegers bred, 8 relatively undisturbed pairs had 12 to 13 per cent success based on number of eggs laid. Two pairs ( 25 per cent) each raised one chick. One chick from a late renesting, although alive when I left, was not considered to have fledged. In years when breeding jaeger populations were low success was also low. Only one chick fledged from 7 nests ( 9 eggs) in 4 low years for which I have data: a success of 11 per cent.

Nest predation destroyed at least 5 of 8 unsuccessful clutches. Two were taken by arctic fox, one possibly by wolf. A fifth clutch, which disappeared with no trace, was probably predated. Three clutches were abandoned because of human disturbance, 2 (1 each in 1964 and 1966) after the adults were trapped and banded; and 1 probably because the nest was located within 10 feet of a wellused trail.

Causes of chick mortality are usually not known. Manniche's observation that only 1 of 2 chicks is usually raised suggests that food competition between chicks 
may be responsible for considerable chick mortality. Savile and Oliver (1964) similarly noted the failure of younger chicks to survive more than two weeks in 1962. In this study, 1 successful pair hatched 2 chicks but raised only 1 . The younger chick could not be found two days after hatching. Younger chicks in enclosed nests tended to lose weight and die (see below), presumably because of competition for food with the older chick. No overt aggression by the older chick towards the younger chick, as has been reported (Maher 1966) for the South Polar Skua (Catharacta skua) was observed.

\section{BREEDING CYCLE}

\section{Arrival}

The long-tailed jaeger arrives in high-arctic Greenland and Ellesmere Island in late May and early June (Parmelee and MacDonald 1960). Arrival varies between years in the same area (Manniche 1910) possibly because of year to year differences in snow or ice conditions. Arrival dates at Lake Hazen are not known as the jaegers were present when observers arrived on 29 May 1963, 2 June 1965 and 3 June 1966. They arrived at Eureka on 30 May and Tanquary Fiord on 31 May in 1966.

\section{Egg laying}

Egg laying dates of first clutches range from early June to early July in higharctic Greenland (Salomonsen 1950). Dates from the Canadian High Arctic are in the same range. Eight egg dates from the Fosheim Peninsula, Ellesmere Island, can be calculated from hatching dates in Parmelee and MacDonald (1960). The dates span 8 days from 16 to 23 June with 5 eggs ( 63 per cent) laid on the first 5 days. Schaaning (in Pleske 1928) recorded dates of first eggs of 17 clutches spanning 18 days from 19 June to 6 July. He gives one later date, 18 July, which may be a re-nest. Eleven ( 65 per cent) of the 17 were laid in the first 5 days.

At Lake Hazen 14 eggs of first clutches were laid in 18 days between 10 and 27 June in 1966. There is no peak date and no apparent tendency to synchrony. Fifty per cent of the eggs were laid in the first 10 days. A second clutch of pair 1 was laid on 8 and 9 July 1966. Egg dates from other seasons at Lake Hazen fall within the 1966 range. Two clutches in 1963 were laid between 16 and 26 June. One egg in 1965 was laid on 20 June, one in 1967 on 22 June, and one in 1968 on 21 June. Six pairs laid between 15 and 18 June 1962 (Savile and Oliver 1964).

While egg laying usually occurs in the latter part of June, there is a surprisingly wide spread in egg laying dates both between years and within populations evident in these data, with no obvious tendency for populations to synchronize their breeding.

\section{Clutch size}

According to Salomonsen (1950) the clutch of the long-tailed jaeger is "constantly two". Manniche (1910) reports the majority of nests had 2 eggs. Parmelee and MacDonald (1960) found 1-egg clutches as common as 2-egg clutches, on the Fosheim Peninsula in 1955. The average of 15 clutches was 1.5 eggs. Clutches 
at Lake Hazen have varied from 1 to 2 (Table 1). It was 1 in low jaeger populations (1964, 1965 and 1968), 1.5 in 1967, and 2 in high jaeger populations (1963 and 1966). The clutch of the female of pair 1 has varied in the same way. In the years 1963 to 1968 it was: 2, 1, 1, 2, 1, 1, respectively. Assuming she was the female present in 1962 (cf. above) she also laid two eggs in that year.

\section{Re-nesting}

I have seen no reference to re-nesting by this species. In this study, pair 1 produced 2 successive clutches of 2 eggs. The first laid on 20 and 22 June disappeared on 29. June. The second clutch laid on 7 and 9 July was begun only 8 days after the disappearance of the first clutch and 15 days after its completion.

Other authors have noted late nests or chicks which may have been from renesting. Schaaning (in Pleske 1928) gives 6 and 18 July as dates of clutch initiation. The latter date particularly could be a second nest. Manniche, also, noted a chick "scarcely a week old" on 17 August, which must have been from an egg laid after mid July.

\section{Incubation period}

There is little information on the incubation period of this species. Manniche says 23 days. Parmelee et al. (1967) observed one egg which hatched in 24 or 25 days. In this study five eggs hatched in a mean incubation period of 24.2 days, with a range from 23 to 25 days.

\section{Hatch}

Eggs usually hatch in the first three weeks of July. Bruggemann (in Parmelee and MacDonald 1960) found a nest on the Fosheim Peninsula hatching out on 15 July 1953. The hatching of the egg or the first egg of 8 clutches on the Fosheim Peninsula in 1955 spanned 8 days from 9 to 16 July (Parmelee and MacDonald).

At Lake Hazen 12 eggs hatched between 4 and 20 July 1966. As with the egg dates, no tendency to synchrony is evident. One egg of the second clutch hatched on 3 August. Dates from other years at Hazen are within the 1966 range as follows: 1 on 18 July and 2 on 20 July (1963); 1 on 14 July (1965); 1 on 16 July (1967); 1 on 15 July (1968). Six clutches hatched between 9 and 12 July 1962 (Savile and Oliver 1964).

\section{Development time}

Pedersen (in Parmelee and MacDonald 1960) reports 3 weeks to fledging followed by 10 days of parental care. Parmelee and MacDonald recorded a chick which left its territory and flew well 34 days after hatching, and it was still attended by adults 42 days after hatching. In northern Alaska 4 chicks flew from one-foot-high nest enclosures in a median of 25 days (Maher 1961). One chick at Hazen in 1968 first flew on 6 August, 21 or 22 days after hatching. It was still present with the adults on 27 August, 42 days after hatch, and 3 weeks after fledging (Bromley, unpublished document).

The young fledge usually in early August, sometimes in late July in Greenland (Salomonsen 1950). On the Fosheim Peninsula Parmelee and MacDonald record 
flying young on 19, 28 and 29 August, and on 9 and 17 August near Slidre Fiord and Eureka. At Hazen Camp chicks begin to fly in the first part of August. The first flying chick was seen on 3 August in 1966 and 11 August in 1968. The latter chick flew well by 23 August. Chicks first flew on 3 August in 1962 and flew strongly by 11 August (Savile and Oliver 1964).

The long-tailed jaeger usually leaves high-arctic Greenland by the end of August (Salomonsen 1950). They leave the north coast of Ellesmere Island by 5 August (MacDonald 1953) and the east and west coasts by the end of the month (Parmelee and MacDonald 1960). There is variation in departure time between years. Territorial jaegers did not breed in the low-lemming year of 1907, and left the breeding area in flocks by the end of June (Manniche 1910). Jaegers left Slidre Fiord 2 weeks earlier in 1953 than in 1954. The difference was not because of inclement weather (Parmelee and MacDonald 1960) and may have reflected poor food supply and general low breeding in 1953.

Adult birds that do not breed or whose breeding has failed usually leave the Lake Hazen area early. At the end of the 1966 season the only adults remaining were those attending chicks. In 1964, a very poor season, all adults left early; no adults except one pair with a chick were seen after 6 August. There are exceptions, however: one 1966 pair (13) whose eggs were destroyed on $18 \mathrm{July}$, was defending territory 21 days later on 8 August. Savile and Oliver (1964) noted several birds still about on 23 August 1962, probably attending chicks.

\section{GROWTH}

Four nests, each with a full clutch of 2 eggs, were fenced for study of chick growth and food habits. This method was used in northern Alaska (Maher 1961), where, when nests were fenced before hatching, the adults fed the chicks and usually at least one of two chicks fledged. In this study none of the nests was successful. Six of the 8 chicks were dead by the age of 4 days, 1 lived 7 days and 1 at least 15 days.

Both chicks at 2 nests were dead very early. At one nest one chick was gone and the other was soaked and dead after a day of heavy rain. The chicks were two, and one and a half days old. There was no evidence of predation, but I think it probable that disturbance of the adults by a predator was responsible for the obvious neglect of the one chick. Two chicks at another nest were three and two days old when taken from the enclosure by a wolf.

Of the older chicks at the other 2 nests one lived for 7 and the other for 15 days. The younger chick in both broods was dead in the enclosure when 2 days old. There was no evidence of violence and both lost weight from hatching. Death was attributed to feeding dominance by the older chick. The chick which lived 7 days was taken by a fox. The eighth chick was released from the nest enclosure when 12 days old because its weight had fluctuated for a week and it had essentially stopped gaining weight. It had gained 41 grams when observed and weighed 3 days later. It was not seen again and presumed predated.

Usable weight data were obtained from 3 of the chicks (Fig. 3). Data on the growth of 5 long-tailed jaeger chicks in northern Alaska are available (Maher 


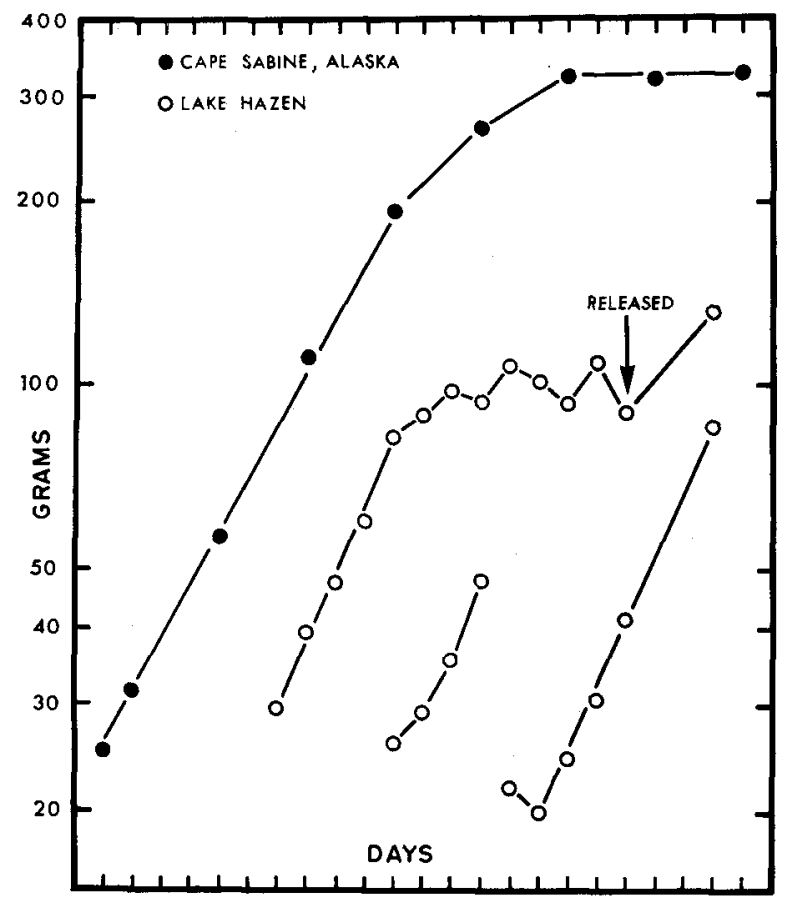

FIG. 3. Weight curves of 3

chicks at Lake Hazen compared with the curve of a chick in northern Alaska.

1961). The Alaskan chicks grew at essentially a logarithmic rate for the first 7 or 8 days after which their growth rate steadily declined and their weight levelled off at approximately 300 grams by fledging. The per cent instantaneous relative growth rate can be calculated for the logarithmic phase (Brody 1945, p. 508) for comparison with the Hazen chicks. The chicks grew logarithmically for 7 to 8 days at a mean daily rate of 22.6 per cent, with a range from 21.7 to 24.6 per cent.

TABLE 2. Per cent relative instantaneous growth rates of 3 long-tailed jaeger chicks, Hazen Camp, 1966.

\begin{tabular}{ccc}
\hline Chick & Days & Growth Rate \\
\hline 1 & $0-4$ & 25.7 \\
2 & $1-7$ & 24.2 \\
2 & $0-7$ & 19.4 \\
3 & $0-3$ & 20.1 \\
\hline
\end{tabular}

The growth rates of 3 Hazen chicks calculated for the logarithmic period are given in Table 2. The rate of chick 2 was calculated in two ways because the chick lost weight between day 0 and day 1 and then grew rapidly (Fig. 3). The chicks grew for three to six days at an average daily rate of 23.3 per cent and a range between individuals of 20.1 to 25.7 per cent. These rates suggest that the growth of the long-tailed jaeger is approximately the same near the northern and southern extremes of its arctic breeding range and that there is no adjustment of growth rate for breeding in the high arctic. 
The collared lemming is apparently the principal food of the long-tailed jaeger in the High Arctic, and year to year fluctuations of the breeding population of jaegers is correlated with changes in lemming numbers (Manniche 1910; Bird and Bird 1940, 1941; Løppenthin 1943; Salomonsen 1950). Parmelee and MacDonald (1960) doubt its dependence on lemmings on western Ellesmere Island. Their reasons are the year to year abundance of jaegers there, the scarcity of lemming sign, and the lack of lemmings in the stomachs of five adult jaegers and in the food regurgitated by a jaeger chick. Their report does, however, suggest a variable breeding population of jaegers with a few breeding in 1953, none in 1954, and a comparatively high population in 1955.

Long-tailed jaegers eat a large variety of food in addition to lemmings. Predation on snow buntings as well as eggs and nestlings of various birds is mentioned by Salomonsen. Predation on Knots and Ruddy Turnstones is conspicuous (Parmelee and MacDonald 1960; Savile and Oliver 1964; and Nettleship 1967). Godfrey (1953) records an adult female jaeger with a snow bunting in its stomach; and Parmelee and MacDonald report that a jaeger chick regurgitated snow bunting remains.

Many authors mention predation by jaegers on insects, L $\varnothing$ ppenthin (1943), and Salomonsen (1950) consider insects to be their chief food in years when lemmings are scarce. They list lepidoptera larvae and adults, diptera (Tipula) and hymenoptera. The stomachs of three of five adults collected on western Ellesmere Island in 1955 had arthropod remains, mostly larvae; and a young jaeger chick regurgitated crane flies (Parmelee and MacDonald 1960). One adult female stomach contained moth caterpillars (Godfrey 1953).

Coastal birds feed on fish (Salomonsen; Parmelee and MacDonald), crustaceans (MacDonald 1960) and exceptionally cephalopods (Bay, in Løppenthin 1943). They have been recorded feeding on several berry species (L $\varnothing$ ppenthin; Salomonsen).

The young are fed on insects for the first 10 to 12 days, then change to lemmings (Pedersen, in Løppenthin). Parmelee and MacDonald record a young chick which regurgitated craneflies (Tipula) and snow bunting remains.

Two hundred and forty-two fresh pellets and 710 old pellets were collected at Lake Hazen in 1966. Contents were analysed as per cent occurrence in the total number. Fresh pellets were analysed separately and divided into adult subsamples according to date and chick pellets from nest enclosures. Arthropod occurrence was analysed only for fresh pellets.

The results (Table 3 ) confirm that breeding long-tailed jaegers depend primarily on the collared lemming for their food supply. The high per cent of lemmings in the old pellets suggests that this is true at low and high jaeger densities, as pellets from populations of all densities are probably included in the sample.

Almost 50 per cent of new pellets contained prey other than lemming; this consisted mostly of arthropods. A comparison of vertebrate prey other than lemmings in new and old pellets shows more in the new, i.e. $18.6 v 8.0$ per cent. The 1966 jaeger population may have been more dependent on such prey than the 
TABLE 3. Per cent occurrence of prey in long-tailed jaeger pellets collected at Hazen Camp, 1966.

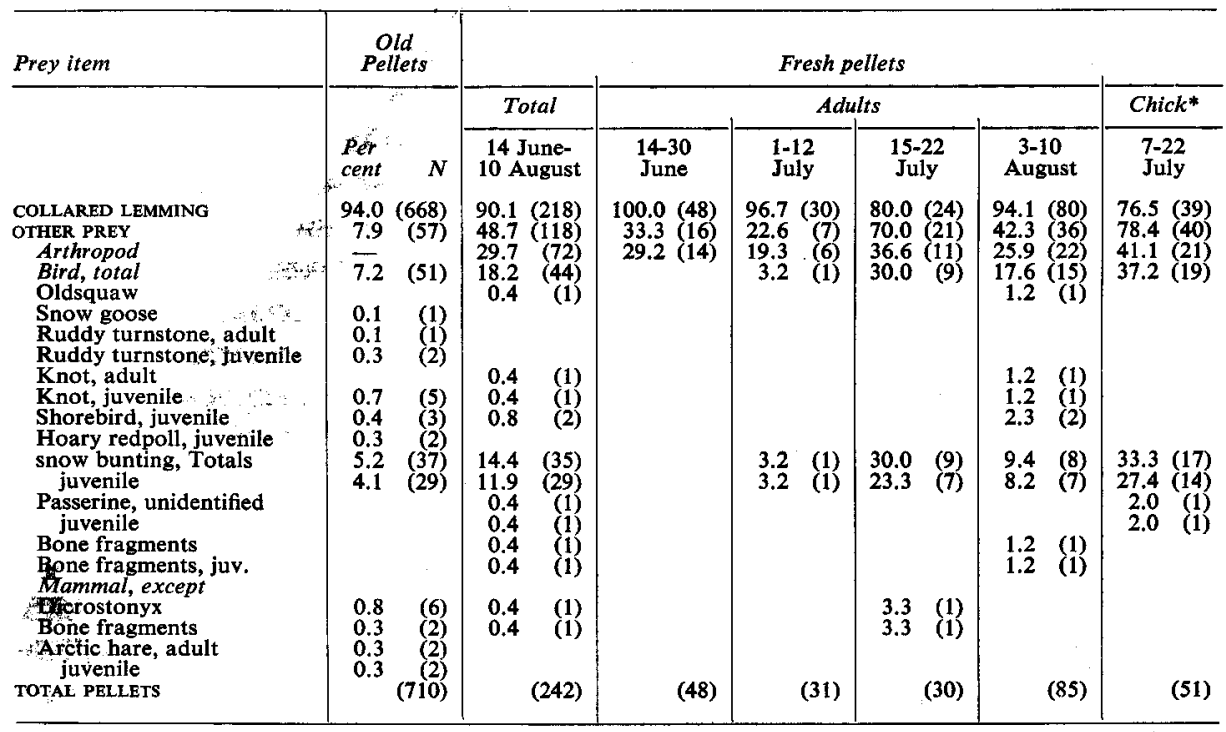

*Includes stomach contents of 3 chicks, not included in total pellets.

average of previous populations, but the difference between the samples is more likely because pellets of bird remains and carrion have little hair or feathers to bind them and they disintegrate rapidly.

Snow buntings occurred most frequently: 79.5 per cent of birds in new pellets, and 72.5 per cent of birds in old pellets. Shorebirds, the other important group of bird prey, were 9.1 per cent in new pellets and 21.6 per cent in old pellets.

Most birds taken were juveniles: 83 per cent of snow bunting and 3 of 4 shorebirds in new pellets; and 79.4 per cent of passerines and 91 per cent of shorebirds in the old pellets.

TABLE 4. Analysis of arthropods in fresh jaeger pellets.

\begin{tabular}{lcc}
\hline Taxon & Per cent & Number \\
\hline Arachnida (S.C. Araneida) & & \\
$\quad$ Lycosidae & 2.2 & 3 \\
$\quad$ Thomisidae & 0.7 & 1 \\
$\quad$ Unidentified & 1.5 & 2 \\
Insecta, Lepidoptera & 3.6 & 5 \\
$\quad$ Noctuidae & 54.7 & 75 \\
$\quad$ Larval Lepidoptera & 19.7 & 27 \\
Diptera & 8.8 & 12 \\
$\quad$ Tipulidae & 3.6 & 5 \\
$\quad$ Larval Nematocera & 2.9 & 4 \\
$\quad$ Unliphoridae (Adult) & 2.2 & 3 \\
Hymenoptified Muscoideae* & 2.2 & 137 \\
$\quad$ Ichneumonidae & 99.9 & \\
\hline Total & & \\
\hline
\end{tabular}

*Fragments only. 
Arthropods in fresh pellets are tabulated (Table 4) as the total number of occurrences of each taxon in the 72 pellets with arthropod remains. The result confirms that jaegers take a variety of insects and arachnids, including some very small forms. Larval lepidoptera and adult tipulidae, however, are the bulk (74.4 per cent) of arthropod occurrences.

Analysis of sub samples of new adult pellets is subject to error because the samples are small and because samples collected after June probably contain some June pellets. However, the samples do show a seasonal trend in food supply from almost exclusively lemmings and a few arthropods in June, to increasing use of other prey. Most birds and all shorebirds are from pellets collected in early August.

The chick food remains are from the middle 2 weeks of July. Chicks appear to be fed a higher proportion of arthropods and birds than adults were eating in the same period. The high proportion of birds may be an artifact, however, as most are from one pair which fed its chick almost exclusively on snow buntings. Chicks are fed pieces of lemming and other large prey from hatching, contrary to the observation of Pedersen, cited above.

Observations of jaegers feeding give interesting supplementary information on their food habits and predator role in the community. They apparently depend on visual sighting to locate lemming prey. Twice a jaeger on the ground flew at least 50 yards to grab a lemming. Three jaegers observed eating lemmings ate the viscera before swallowing the carcass head first. All had difficulty swallowing, and up to four tries were necessary. Frequently they picked at the visceral cavity between attempts. Eviscerating their prey may be necessary before they can swallow moderate-sized to large lemmings.

Jaegers were also observed to take 3 turnstone chicks; 2 taken on 3 August were just fledged. One jaeger unsuccessfully pursued an adult snow bunting on 26 June.

Jaegers frequently walk about and apparently snap up insects. One adult fed on drifts of chironomids along the shore of Lake Hazen. Observations of jaegers eating insects were from 17 June to 8 August.

\section{DISCUSSION}

\section{Population changes}

Breeding populations of the long-tailed jaeger in the High Arctic vary greatly in density between years. Evidence from northeast Greenland correlates these changes with the fluctuations of the collared lemming population (see especially Løppenthin 1943), and suggests that the jaeger in the High Arctic is an obligate lemming predator adapted to exploit lemming population highs, and that it must have sufficient lemmings to provide most of its food in order to breed.

Changes from year to year in the numbers of jaegers breeding at Lake Hazen also suggest that the population size is correlated with a lemming population cycle. There are no quantitative data on the lemming population at Lake Hazen, but the evidence does suggest regular fluctuation in numbers. The available observations can be briefly summarized. A peak lemming population occurred 
at Lake Hazen in the summer of 1957 . The population crashed during the succeeding winter and lemmings were very scarce the following summer (Tener in Savile and Oliver 1964). There are no data for 1959 and 1960 . No lemmings were seen in 1961. Seven were recorded in 1962 by Savile and Oliver and all seen closely were juveniles, indicating an expanding population. Jaegers bred in numbers that year and an active fox den with 2 cubs was located on the area. Only 6 lemmings and a number of weasels were seen in 1963. No live lemmings were seen in 1964 or 1965 although a few carcasses were found in 1964 and a few burrows in snow, and lemming tracks were noted in early June 1965. Moderate numbers of lemmings were present in 1966. Winter nests were common (25 were described in my field notes) and 77 lemming specimens were obtained. The lemming population peak, however, was in 1967, as many more lemmings were seen in that summer than in the previous one. Many winter nests were found on the study area in 1968, but only one lemming was seen.

These observations while fragmentary suggest a 5-year cyclic fluctuation of the collared lemming with a peak in 1957, a low peak in 1962, a high peak in 1967 preceded by a moderately high population in 1966, and a decline in the winter of 1967-68. The changes in the numbers of breeding jaegers from 1961 to 1968 suggest that the population is dependent on the lemming population as in northeast Greenland although observers reported a lower population of jaegers in 1967 than in 1966. The analysis of the pellet contents also confirms that jaegers breeding at Lake Hazen are utilizing mostly lemmings for food.

Parmelee and MacDonald (1960) found no evidence that long-tailed jaegers were dependent on lemmings on western Ellesmere Island, but I am unable to evaluate their evidence. Some long-tailed jaegers do breed in low lemming years at Lake Hazen, but the analysis of old pellets collected in 1966 suggests that they are feeding primarily on lemmings even in those years. Since they take mostly juvenile birds which are available for a short period in midsummer, they cannot depend on birds entirely as an alternate food. Insects, birds' eggs and carrion would seem to be the only alternative food in early summer except for coastal pcpulations which could use fish. There is no evidence that long-tailed jaegers can feed for extended periods exclusively or even primarily on insects.

\section{Territoriality}

Breeding long-tailed jaegers occupy large territories upon which pairing, nesting and most food gathering takes place. An all-purpose territory (Type A of Nice 1941) is characteristic of all jaegers of the genus Stercorarius (Maher 1961) in northern Alaska.

Evidence regarding the permanence of these territories is not clear. Manniche (1910) witnessed a population which returned to an area in which it had bred the previous season, occupied territories and then departed without breeding because of a low lemming population. Similar behaviour by a long-tailed jaeger population was observed on Banks Island, N.W.T. in 1963 (Maher 1964). A population of seven pairs was established on 2.5 square miles of tundra in mid June. Copulation was observed by 2 pairs between 15 and 17 June. Two pairs laid clutches of 1 egg each which were located on 21 June when all other pairs 
had departed. These nests failed by 29 June and 3 July. Swanberg (in L $\phi$ ppenthin 1943) witnessed similar events in Swedish Lapland.

These observations definitely suggest that long-tailed jaegers return to territories in the High Arctic once they are established. It is not known how frequently conditions must be satisfactory for breeding in order that the pair will maintain attachment to the territory.

At Lake Hazen relatively high populations of jaegers have bred in only 2 of 7 years from 1961 to 1966 , with 4 years between the peak years. Banding results show that one territory was occupied for 6 consecutive years by 1 female and 2 successive males and that 1 other territory was occupied for 2 of 3 years by a pair with one banded member. Nest locations between years also suggest that one other territory was occupied 2 of 3 years by the same pair. There is no evidence that other pairs present in 1966 had bred in the area before, and many failed to breed in 1964 and 1958. These observations seem to suggest that long-tailed jaegers tend to occupy permanent territories when breeding is possible frequently enough to reinforce the territory bond. Manniche (1910), for example, witnessed 2 successful breedings in 3 seasons with a low non-breeding year between the 2 peaks. Possibly if the lemming population in an area remains low for several years most or all territories will be abandoned. Jaegers breeding in lemming peak years in such areas will consist of a few pairs which have attempted to breed each year, and transient pairs which locate the lemming high and remain to exploit it. This explanation is consistent with the population changes at Lake Hazen.

\section{Adjustment of clutch size}

In addition to adjusting its population density, the long-tailed jaeger can apparently adjust its clutch size to the level of food supply when it does breed. Clutches in high populations are usually 2, as at Lake Hazen in 1962 and 1966. Parmelee and MacDonald (1960) reported a high percentage of 1-egg clutches in a population on the Fosheim Peninsula in 1955 which they attributed to the low lemming population. Observations on Banks Island, cited above, and the data from Lake Hazen indicate that average clutches are smaller in poor than in high lemming years. The record of the female of pair 1 indicates further that small clutches are not necessarily from inexperienced females in a population, but that the clutch of individual females varies according to environmental conditions, presumably food supply.

\section{Adaptations to the High Arctic}

Several features of the long-tailed jaeger's biology adapt it to the High Arctic. Its small size compared with the other lemming predator in the genus Stercorarius, the pomarine jaeger, allows efficient use of lemming highs whose absolute densities may not be very great and which may also be both local and infrequent.

Its relatively small size also allows the species to make significant use of insect prey. Several authors (Løppenthin, Salomonsen) regard insects as the most important food of the jaeger in non-lemming years. The results of this study put the importance of insects to breeding jaegers far below birds as an energy source, although they are probably an important supplement to the jaeger's diet when 
other food is scarce. The real significance of insects to the jaeger may be as food for chicks. The data presented here do seem to show that chicks eat proportionately more insects than adults do, and other authors (Parmelee and MacDonald, Pedersen in Løppenthin) have noted insects in the food of chicks. Two free chicks which I observed at Lake Hazen persistently picked up insects. The chick released from the nest enclosure in the growth study gained 41 grams in three days after release (Fig. 3). The gain is attributed to its freedom to forage for insects. Longtailed jaeger chicks may, in fact, do a significant amount of their own feeding.

Growth of the 3 jaeger species is essentially the same in the initial logarithmic phase of growth (Maher 1961). The comparatively small size of the long-tailed jaeger results in its maturing more rapidly than the other 2 species.

Fledging time in the long-tailed jaeger is about 3 weeks. Seventeen pomarine jaegers at Barrow in 1960 fledged from one-foot-high nest enclosures in an average of 31.3 days; range 28 to 34 days. Observations suggest an additional attendance by adults of at least two weeks. The parasitic jaeger fledges in 29 to 30 days (Perry 1948). In northern Alaska three fledged from enclosed nests in 28.1 days (Maher 1961). Thus the long-tailed jaeger has an advantage of 1 week to 10 days in average fledging time over its closest competitor, the pomarine jaeger. The advantage of this is evident if we assume that long-tailed jaeger can fledge and be completely independent in 40 to 45 days, then eggs laid as late as the end of June have a reasonable chance of producing successful young by the end of August.

Short development time also gives the jaeger some latitude in timing its breeding cycle even in the short high arctic season. It is usually exploiting a food supply (lemmings) which when they are abundant enough to support jaeger breeding would be a comparatively dependable food source through the season. Other major food categories in the jaegers' diet, insects and insect larvae (Nettleship 1967) and juvenile birds have marked seasonal peaks of abundance in the Arctic. Dependence on such a food supply for feeding the young should induce a tendency to synchronize breeding of the jaeger. Relative dependability of the lemming population as a food supply within a season could account for the pronounced lack of synchrony in egg laying of this species. It allows jaegers up to several weeks after arrival on the breeding grounds to locate a suitable breeding area. Jaegers may also be prevented from depending more heavily on birds by the low density of bird populations in the High Arctic.

\section{Comparison with north Alaska populations}

Long-tailed jaegers breed in the northern foothills of the Brooks Range and the southern part of the coastal plain north of the foothills. They do not breed on the northern coastal plain in an area in which the brown lemming (Lemmus trimucronatus) population cycle occurs. I have concluded elsewhere (Maher 1961) that their absence from this area is because of competitive exclusion by the larger pomarine jaeger. Where the long-tailed jaeger does nest in northern Alaska it typically occupies large permanent territories upon which established pairs breed each year. Densities in 1 such area varied from 0.66 to 1.3 pairs per square mile between years. Their food supply was primarily several species of microtine 
rodents and birds. Proportions of these two food categories varied between years but averaged 45.6 per cent microtine rodent and 54.0 per cent birds for 3 years (Maher 1959, 1961).

Local microtine rodent highs occur rarely in the foothills and long-tailed jaegers do exploit them. In 1959 a high of Microtus oeconomus occurred at Cape Sabine and was exploited by a long-tailed jaeger population breeding at a density of 2.3 pairs per square mile; this was comparable to peak densities found at Lake Hazen, and higher than those from typical foothill tundra. Food supply of this population was 90 per cent microtine rodent and 9 per cent birds (Maher 1961). Thus the long-tailed jaeger in the southern part of its range maintains a more stable population than it can in the High Arctic. It accomplishes this by expanding its food niche so that approximately $\mathbf{5 0}$ per cent of its food is birds, and by breeding at lower density than it does in the High Arctic in a good lemming year. The reduction in density in the south may be the result of competition with the parasitic jaeger which occupies essentially the same habitat as the long-tailed jaeger in northern Alaska; or of reduced hunting efficiency of the jaeger when depending heavily on birds and when hunting microtine rodents in the tussock tundra vegetation characteristic of that area (See Maher 1959, 1961).

\section{ACKNOWLEDGEMENTS}

These observations were made in association with work on the program "Studies on arctic insects", Entomology Research Institute, Canada Department of Agriculture, in collaboration with the Defence Research Board of Canada.

The Defence Research Board of Canada kindly provided logistic support and permitted the use of the Hazen Camp facilities. I am grateful to D. R. Oliver, Entomology Research Institute, Canada Department of Agriculture, for arranging the logistics and for allowing me to use notes taken in 1963, 1964 and 1965 by several of his collaborators.

I gratefully acknowledge financial support from the Institute for Northern Studies and the President's Research Fund, University of Saskatchewan, and the National Research Council of Canada.

R. Leech generously contributed field observations made in 1963 and 1964, as well as helpful information on problems of studying jaegers in the Hazen area. 1965 field notes are by M. Colbo. Observations in 1967 were by P. G. Kevan and J. D. Shorthouse; in 1968 by P. G. Kevan and G. Bromley. D. N. Nettleship helped me in the field. Pellet contents were analysed by $\mathbf{L}$. Smith, and arthropod remains were identified by D. J. Karasiuk.

\section{REFERENCES}

BIRD, C. G. and E. G. BIRD. 1940. Some remarks on non-breeding in the arctic, especially in north-east Greenland. Ibis, series 14, 4: 671-78.

1941. The birds of north-east Greenland. Ibis, series 14, 5: 118-61.

BRODY, S. 1945. Bioenergetics and growth. New York: Reinhold Publishing Co. 1023 pp.

CORBET, P. s. 1967. Screen temperatures during the summers 1962-1966 at Hazen Camp, Ellesmere Island, N.W.T. Ottawa: Defence Research Board. (D. Phys. R. (G) Hazen 30). $11 \mathrm{pp}$.

GODFREY, W. E. 1953. Notes on Ellesmere Island birds. Canadian Field-Naturalist, 67: 89-93. 
LФPPENTHIN, B. 1943. Systematic and biologic notes on the long-tailed Skua Stercorarius longicaudus Vieill. Meddelelser om Gronland, 131: 1-26.

MACDONALD, S. D. 1953. Report of biological investigations at Alert, N.W.T. National Museum of Canada Bulletin, 128: 1-16.

1960. Report on biological investigations at Isachsen, Ellef Ringnes Island, N.W.T. National Museum of Canada Bulletin, 172: 90-97.

MAHER, W. J. 1959. Habitat distribution of birds breeding along the upper Kaolak River, northern Alaska. The Condor, 61: 351-68.

1961. The ecology of the pomarine, parasitic and long-tailed jaegers in northern Alaska. Ph.D. thesis, University of California, Berkeley. 385 pp.

1964. A comparison of the ecology of lemming predators on Banks Island, Canada, with those of northern Alaska. Progress report to Arctic Institute of North America, Project no: ONR-318. 31 pp.

1966. Predations impact on penguins. Natural History, 75: 42-9.

MANNICHE, A. L. v. 1910. The terrestrial mammals and birds of north-east Greenland. Meddelelser om Grønland, 45: 1-200.

NETTLESHIP, D. N. 1967. Breeding biology of Ruddy Turnstones and Knots at Hazen Camp, Ellesmere Island, N.W.T. M. Sc. thesis, University of Saskatchewan, Saskatoon. 175 pp.

NICE, M. M. 1941. The role of territory in bird life. American Midland Naturalist, 26 (3): 441-87.

OLIVER, D. R, and P. S. CORBET. 1966. Aquatic habitats on a high arctic locality: the Hazen Camp study area, Ellesmere Island, N.W.T. Ottawa: Defence Research Board. (D. Phys. R. (G) Hazen 26.) 115 pp.

PARMELEE, D. F. and S. D. MACDONALD. 1960. The birds of west-central Ellesmere Island and adjacent areas. National Museum of Canada Bulletin, 169: 1-103.

PARMELEE, D. F., H. A. STEPHENS and R. H. SCHMIDT. 1967. The birds of southeast Victoria Island and adjacent small islands. National Museum of Canada Bulletin, 222: 1-229.

PERRY, R. E. 1948. Shetland Sanctuary. London: Faber and Faber. 300 pp.

PLESKE, T. 1928. Birds of the Eurasian tundra. Boston Society of Natural History, Memoirs, 6 (3): 111-485.

SALOMONSEN, F. 1950. Grønlands fugle; the birds of Greenland. Copenhagen: Ejnar Munksgaard. $608 \mathrm{pp}$.

SAVILE, D. B. o. 1964. General ecology and vascular plants of the Hazen Camp area. Arctic, 17: 237-58.

SAVILE, D. B. o. and D. R. OLIVER. 1964. Bird and mammal observations at Hazen Camp, northern Ellesmere Island, in 1962. Canadian Field-Naturalist, 78: 1-7. 